\title{
BOOKREMEW
}

\section{【 テーマ書評シリーズ——69}

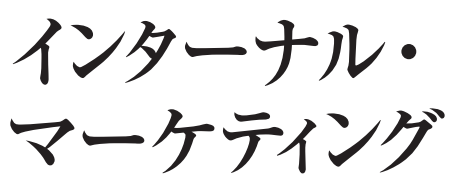

森村 文一

神戸大学大学院 経営学研究科博士課程後期課程

\section{৯はじめに}

本稿は, サービス・マーケティング研究にお ける，インターナル・マーケティング（以下， IM）に関する議論を整理し，その知見を確認 し課題を理解する事を目的とする。サービス取 引においては，1）サービスにおける生産と消 費の不可分性，2）顧客のサービス生産への直 接関与という点から, サービス取引全体の知覚 品質に影響を与える従業員と顧客の直接的かつ 人的な相互作用としての接点をどう設計・管理 するかという点が重要な問題となる。この問題 について，顧客接点にいる従業員だけでなく， 組織内の全ての従業員が顧客の為にサービス提 供を行うという顧客志向の醸成を，組織的に管 理的側面から捉えるアプローチがIM である。

サービス・マーケティング研究は, その分野 を確立するに至る 1960 年代のサービス自体の 概念規定（例えば，Judd, 1964; Rathmel, 1966; Regan, 1963）を基礎に, Bateson（1979）の主 張した，無形性が故にサービスが直面する問題 についての分類が，サービス・マーケティング 研究の出発点である（山本, 1999)。Bateson （1979）はサービスの生産と消費の同時性から, 1）サービスからの顧客の不可分性，2）サービ ス提供者または環境からの顧客の不可分性，そ れが故の 3）生産・マーケティング・人事機能 の不可分性, という “顧客関与” “品質管理”
“組織的軋轢の管理”の 3 点がサービス・マー ケティングにおいて議論されるべき重要な問題 であるとしている。Bateson (1979) 以降, サ ービス・マーケティング研究はサービスの問題 特定的な焦点において研究蓄積が行われていく 事となるが, 最も重要な研究分野として, サー ビス品質に関するものが挙げられる。このサー ビス品質に関する研究の代表的研究に Parasuraman et al. (1988) が主張した SERVQUAL がある。これはサービスに対する 品質の事前期待と知覚評価の差異によってサー ビス品質を測定するモデルである。この Parasuraman et al. (1988) 以降, 顧客満足と の関連を含めて, 多くの研究者によって盛んに 議論が行われる分野となっている（例えば, Babakus and Boller, 1992; Bitner, 1990; Carman, 1990; Cronin and Taylor, 1992; Crosby et al., 1990; Oliver, 1980)。

サービスが生産され顧客に提供されるサービ ス・デリバリー・プロセスにおいては，顧客が 参加する，つまり顧客がサービス企業の従業員 と協㗢する事になる。“真実の瞬間（Carlzon, 1987)”と呼ばれるこの従業員と顧客の直接的 人的相互作用 $=$ サービス・エンカウンターは, サービス・デリバリーが完了するまで継続し， 提供されるサービスの品質や顧客満足を決定す る重要な要因となるのである（例えば， Bateson, 1991; Solomon et al., 1985)。それぞれ のサービス・エンカウンターがサービス・デリ バリー・プロセス全体のサービス品質や顧客満 足を決定するという事は即ち, サービスを提供 するプロセス全体を厳重に設計・管理する事必 要不可欠となる。なぜならこのサービス・デリ バリー全体の品質管理 (Total Quality Management: TQM）は製品の製造管理とは異 なり, サービス・デリバリー・プロセスに参加 するのが従業員及び顧客であり標準化が困難な 為である（Gummesson, 1991; Shostack, 1984, 1987)。サービス・デリバリー・プロセス全体 
テーマ書評シリーズ

の品質には, サービス・エンカウンターにおけ る従業員の態度や行動が重大な影響を与えるが, それに加えて，顧客との直接的な相互作用を伴 わないバックルームにおいても，効果的かつ効 率的にサービス・エンカウンターにおける従業 員の活動を支援する体制が整っている事が求め られるのである（藤村, 1995）。

つまり, 組織内の全ての従業員が顧客の為に サービス・デリバリーを遂行し，結果的にサー ビス品質を高める様に組織的に管理する事が必 要不可欠となるのである。この問題に焦点を当 てて議論が行われているのが，本稿で整理を行 う IM である。以下，IM に共通する，従業員 の管理問題, つまり従業員を内部顧客, 職務を 内部製品として捉えるという考え方を出発点と したIM 概念の概観を行う。続いて，IMの主 要な関心である，組織的に従業員や組織をどの 様に管理するのかという人的資源管理的側面に 焦点を当てた研究のレビューを行う。次に，人 的資源管理的側面の研究の知見を基に，IM の 視点からナレッジ・マネジメントを捉える試み を行ったナレッジ・マネジメント的側面に焦点 を当てた研究のレビューを行う。そして最後に， IM 研究における研究課題をまとめる。

\section{ネ インターナル・マーケティングの基本姿勢}

顧客のニーズやウォンツを満たす事を専門に 扱うマーケティング部門がその機能を適切に発 揮するためには，組織内のあらゆる部門が，協 働することが求められている ${ }^{1)}$ 。 Lings（2000） や Piercy and Morgan (1991), Varey (1995) を始め多くの研究者が指摘するように，組織と して統合的なマーケティングが必要であるとさ れてはいるが，現実的には，部門間の利害は決 して同じではなく，加えて業務に対しての考え 方や姿勢, 従業員の特性などが異なるため, 多 くの企業が実践上の課題に直面しているのであ る。統合的マーケティングを実現するためには， 1）マーケティング部門内の諸機能の統合，2）
マーケティング部門以外の部門がマーケティン グ発想で考える必要性，3）マーケティング部 門と他部門の連携，が不可欠となる。言い換え ると，研究開発や生産，財務，人事，購買部門 など，あらゆる部門が顧客のニーズやウォンツ の充足を第一に考えて，つまり顧客志向の下働 いていることが条件として求められる。図一 1 にある，Albrecht（1988）が主張する“逆さ まのピラミッド”が示す様に, 顧客志向の醸成 を実行している企業は，トップマネジメントの 役割は，優秀な中間管理職の確保と支援であり， その中間管理職は，顧客接点で働く従業員を支 援するという体制が組まれている。それは，有 効かつ効率的に顧客価值を最大化させるための ビジネスの基本姿勢と言える ${ }^{2)}$ 。

つまり，マーケティングを有効かつ効果的に 実施するためには，組織内の部門間の連携や， 従業員の動機付けによる顧客志向の醸成といっ た管理が重要となり，その論点において議論が 行われてきたのがIMである。しかしながら， その IMの定義に関して言うと，どのような問 題や現象を対象に研究を行うか, 状況に依存し て定義が少しずつ変わり，統一された定義は存 在しないという指摘もされている（Rafiq and Ahmed, 2000)。

例えば，組織内の従業員をどう管理するかに ついての議論が始められる 1980 年代の代表的 研究においては,「組織の目的に注意を向ける 一方で，従業員を内部顧客と見なし，従業員の 行う業務を内部顧客のニーズを満たす内部製品 と見なす (Berry, 1981)」ことが重要であり， 「IM の目的は，従業員を動機付け，顧客に対 して意識的な人材を獲得することである (Gronroos, 1981)」とされている。つまり， Berry and Parasuraman（1991）が指摘するよ うに，顧客にサービスを提供する従業員の動機 付けの方略として位置づけられていたのである。 1990 年代には, 組織内の各部門における顧客 志向の不均衡が議論の対象となり, 例えば 
逆さまのピラミッド

(a) 伝統的な組織図

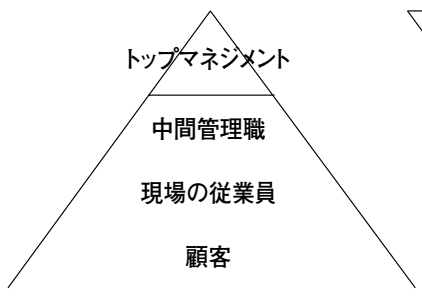

(b) 顧客志向企業の組織図

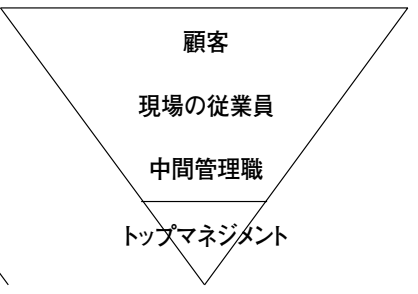

Albrecht (1988)，p107.より筆者修正。
Rafiq and Ahmed（1993）は「IM とは，変化 に対する組織的抵抗を克服し，全社的・職務的 戦略の効果的な実行に向けて, 従業員を協力さ せ，動かし，まとめるための計画された努力」 と定義している。2000 年に入ると, 代表的な 視点は 2 分化する。1つは, 1980 年代からの議 論を基礎に, 顧客満足と従業員の職務満足との 因果関係とそれに対する組織的取り組み (Vasconcelos, 2008) や，IM の組織的有用性 (Ahmed et al., 2003) という視点である。もう 1つは, これまでの議論の焦点であった, 組織 内の各部門の統合と従業員の動機付けに対する 組織的取り組みという視点に止まらず，組織行 動の有効性や経営計画の効率的な実現のために は, 組織内に散在する知識を集約し, 新たな知 識を創造するプロセスを効果的に回すことが重 要である（Ballantyne, 1997, 2003）という視点 である。

統一された定義が無いということはつまり， IM にはいくつかの形態があるということであ るが, 共通する点は, 「顧客は市場のみではな く組織内部にも存在しており, 内部顧客として の従業員も外部顧客に用いられるのと同様のマ ーケティングの対象になるという認識（Baron and Harris, 1995)」であると言える。

\section{ネIM における 2 つの観点}

\section{1. 人的資源管理論的アプローチ}

\section{1. 内部市場と IM}

サービス生産と消費の同時性が故に, サービ スの提供には顧客が関与するが，それと同時に 従業員も関与しているため, 組織的に従業員を 管理する事が重要であるとする視点が IM 研究 の出発点である。その先駆的研究がSasser and Arbit (1976) と Berry（1981）である。 彼らは仕事に従事する従業員を，仕事という製 品を選択した顧客であると捉え，「マネジャー は従業員の仕事を単なる与えられたタスクでは なく, 従業員にとって期待される価值のある特 性を含む仕事として構築し，それを製品として 捉えることで彼らの満足を向上させることが可 能となる。IMは従業員を内部顧客, その従業 員の仕事を内部製品として考える経営哲学であ る。企業目標を達成すると共に, 内部顧客の二 ーズやウォンツを満たすために内部製品を提供 することを目的とする (Berry, 1981)」と主張 している。つまり，サービスを提供する企業は 外部市場へのマーケティングに先立ち, 組織内 部の市場に対してマーケティングを行う事が重 要であるという視点である。この主張と同様に， 
Gronroos (1981) やZaithmal et al. (1988) も 従業員の捉え方に触れ，マーケティング戦略や その他の戦略の実行に際して, 従業員へのコミ ユニケーションは注意深く行われるべきである としている ${ }^{3)}$ 。

これらの，顧客のニーズやウォンツを満たす ために，まずは従業員のニーズやウォンツを満 たす事が重要であるという先駆的研究を基盤と して，組織の人を扱う人的資源管理部門とモノ や情報を扱うマーケティング部門の連携や，従 業員の顧客志向への動機付けの重要性が議論さ れるようになる。即ち，組織と外部環境との人 員調整や従業員の教育・訓練を担う部門として の位置付けであった人的資源管理部門が，組織 内部に対してマーケティング・アプローチを用 いる事で，組織の各部門の生産性を効果的に向 上する事が出来ると考えたのである。つまり， George（1990）が主張するように，IM は組織 内の各部門を連携させるための全体論的経営プ ロセスであり，組織内の人材を活用するための 哲学であり，それは人的資源管理部門とマーケ ティング部門が連携することで達成されるので ある（Glassman and McAfee, 1992）。また, 採用や教育，従業員の動機付けや報酬に関して も，マーケティング志向の考え方が人的資源部 門に求められているとされている（例えば, Bowen and Lawler, 1992, Collins and Payne, 1991, Rafiq and Ahmed, 1993)。同様の視点か ら, Berry and Parasuraman（1991）は IM を 7 つの活動，即ち 1）人材を引き付ける，2）採 用時のスクリーニング，3）教育，4）選抜，5） 知識・経験・情報の共有, 6) 社外への発信, 7) 評価と賞賛，であると整理し，IM コンセプト を戦略レベルと戦術レベルという2 段階で捉え ている。これらの主張点を，先に述べた Albrecht（1988）の顧客志向組織の“逆さの ピラミッド”に即して捉え直すと，トップマネ ジメントが顧客志向を醸成するように経営方針 や人事政策を支援し，中間管理層が組織の内部
市場の重要性を認識し社内教育や経営計画の遂 行を支援し業務を構築することが重要となる。 このように組織的に顧客志向を酮成するため, IM が効率的かつ効果的に展開されるためには, 従業員が高いレベルで動機付けられ，更に顧客 志向でなければならない。さらにその前提とし て，必要とされる態度用件を備えた従業員を選 抜し，留めておくことが求められるのである (Berry and Parasuraman, 1991)。この従業員 を管理する点について Gummesson（1987）も， 「顧客接点にいるフロントラインの従業員は “パートタイム・マーケター”としての役割が 求められる」としており，人的資源管理にマー ケティング手法を用いる事の重要性を強調して いる。

さて，IM の議論における焦点は，顧客志向 を醉成するためにまず従業員のニーズやウォン ツを満たすという組織的取り組みにあるが，従 業員が顧客志向を持つことによる組織的有用性 について，1）従業員－顧客，2）組織－市場の レベルで捉えたのがNorman（1991）である。 彼は，従業員が自身の職務に満足した状態であ ることが重要であるとし，満足した従業員が顧 客の気分を高揚させ満足させ，さらにそのよう な満足した顧客から従業員は更なる満足を受け ると主張している。このフロントラインにおけ る循環を “良いミクロの循環” と呼び，この循 環が強力なサービス・マネジメント・システム を構築する基盤となり，企業に成果をもたらす という“良いマクロの循環”が形成されると強 調している。重要な点は，この良いミクロの循 環は自然発生的に形成される訳では決して無く, 同様に良いミクロの循環が自然発生的に良いマ クロの循環を形成する訳では無いということで ある。これらの循環を良好な状態で回すために は，IM研究において主張されてきた様に，組 織的な管理や支援が必要不可欠となる ${ }^{4)}$ 。特に, マネジャーの指導力とコミュニケーション能力 の不足，責任や評価基準の不明確さといった運 
営管理上の問題だけでなく, 組織としての従業 員への動機付けの欠如, 職場での協力の雲囲気 の欠如, そして社内の情報共有の仕組みと意識 の欠如が問題であると指摘されている。

これら一連の研究においては, 外部市場に先 立って組織の内部市場にマーケティングの理念 や手法を用いる必要性についての議論が中心で あった。その後, Norman（1991）においても 触れられているが, 組織内には変化に対しての 障壁が存在し，それにより “IM 不均衡”が発 生しているという点に議論が進んでいく（例え ば, Ahmed and Rafiq, 1995; Piercy and Morgan, 1991)。中でも, Ahmed and Rafiq （1995）はIM のマルチレベル・モデルを提示 しており，実際にIMのアプローチを導入した 生命保険会社の事例研究を行っている。その組 織内の IM 不均衡の克服の重要性については, 彼らの「IM とは, 変化や調整, 連携に対して の組織的抵抗に打勝ち, 全社的・職務的戦略の 効果的な実行に向けて, 従業員を動機付け, 連 携させることである」という定義にも表されて いる。彼らはその中で, 効果的な IM の実行を 3つのレベルで捉えなければならないと主張し ている。それは, 特定の任務や変更プログラム といった組織的努力の方向性の定義（レベル 1： direction), 直面するであろう障壁の把握 やその克服のための潜在的方法の検討（レベル 2 : path), 実行のための効果的な IM 施策の 戦術的展開（レベル 3 ：action）である。特に 重要となるのは, レベル 2 における障壁の把握 と, レベル 3 における IM 施策の戦術的展開で ある。Ahmed and Rafiq（1995）においては, 障壁は 3 つに分類され，1）概念的障壁，2）人 的障壁, 3）仕組みの障壁 - 意識/能力の障 壁・費用 / 有効性障壁・場的環境的障壁, が指 摘されている。レベル 3 において, これらの障 壁を把握し, その克服へ向けて IM の戦術的展 開が行われる。このIM 施策の効果的な展開の ためには，プロセス・価格・プロモーション・
場所といったインターナル・ミックスの各要素 の厳重な管理を行う事が要求される。その中で も, 組織内の顧客志向を醸成するためには，プ ロセスとプロモーションが特に鍵となる。プロ セス要素は組織的構造や報酬システム, 権限や 責任, リーダーシップであり, 必要不可欠な職 務や目標の実行のために，これらに注意するこ とが求められる。また, プロモーション要素は 組織内に向けられたプロモーション計画といっ たコミュニケーションとしての活動であり, 従 業員による計画の受け入れといった，知識やス キル, 戦略的変化への意識を増加させるために 重要となる。つまり, 従業員に何をすべきか, いつそれを行うのか, どのように行うかを知ら せ, 戦略上の従業員自身の役割を明確化させる 極めて効果的な媒体となる。これらの研究が示 すのは，全てのマーケティングの理念や手法が 内部市場に有効という訳では無く, 経営者は内 部市場の特性を適切に判断し, どのような施策 が適切で，どのように適用すべきかについて， 慎重に検討する必要性が強調されている。

一方, 内部市場の細分化と, 細分化された各 市場に対してのIMの戦術的活動に焦点を当て た議論も行われている。Collins and Payne （1991）は，人的資源管理部門が対象とすべき 内部市場は 3 つると指摘している。それは 1) 組織内の従業員, 2) CEO を含めたマネジメン 卜業務に関わる経営者層, 3) 今後自社の従業 員になる可能性のある人・政府・組織・その他 エージェント，である。その上で，人的資源管 理部門には，(1)これら 3 つの市場のニーズやウ オンツの把握, (2)その実現のためのプロジェク トの設計・実行・フォローアップにおける他部 門との連携，(3)その実現による組織的有効性の 把握, を徹底的に行うことが求められると主張 している。これら IM の戦術的な活動を, 組織 目標における重要度とカスタマイズの必要性と いう 2 軸で捉えている点が特徽的である ${ }^{5)}$ 。 


\subsection{IM と組織的成果との関係}

上記の IM 研究において, 特に人的資源管理 部門とマーケティング部門との連携に焦点を当 てた研究においては, IM とは何か, どのよう な活動が行われるべきか, どのように IM 施策 を適用するのか，という理念と施策の抽出のた めの事例研究を中心に議論が発展してきた。し かしながら，実際にそのIM の実施が企業の成 果に正の影響を与えているのかについては，ほ とんど研究が行われていないと指摘されており (Ahmed et al., 2003)，つまり，高成果を挙げ ている企業を事例分析対象として選択すること で，企業の成果が前提として扱われていると言 える。

Ahmed et al. (2003) は, 図一2に示すよう に, IM ミックスと組織能力（市場志向行動, 従業員満足, 特定的・個人的コンピタンス), そしてそれらが事業成果に影響を与えるという モデルの実証分析を行っている。彼らの研究に おいては, IM ミックスは図ー2に示すように 11 の変数で操作化されている。この研究にお いて, 因子分析の結果 IM ミックスには 3 つの サポート・ミックスが存在することが明らかに なっており，それは1）トップマネジメント・ 口図一2

IM とミックスと事業成果のモデル

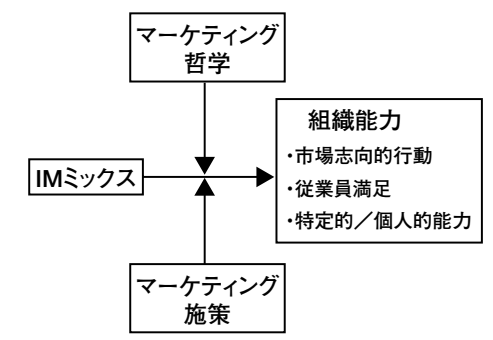

Ahmed et al. (2003), pp.1223, 1226 より筆者修正。
ミックス，2）事業プロセス・サポート・ミッ クス，3）部門間連携ミックス，である ${ }^{6}$ 。そ して, それら IM ミックス及び組織能力が事業 成果に正の影響を与えることが実証されている。 加えて, モデレータとしてのマーケティング哲 学や施策であるが，マーケティング施策は IM ミックスの実施にのみ正の影響を与えるが，マ ーケティング哲学については, IM ミックスの 実施と組織能力の両方に正の影響を与える事が 明らかにされている。

多くの IM 研究においては, 高成果の企業を 事例として選択することで，成果を前提に議論 が行われていた。つまり, IM の実施が本当に 企業の成果に正の影響を与えているのかという 疑問に対しては，明らかにされていなかったと 言える。その点において Ahmed et al. (2003) の実証研究は，それまでの IM 議論を支持する 重要な研究であると考えられる。

\section{2. ナレッジ・マネジメント・アプローチ}

Sasser and Arbit (1976) と Berry (1981) の内部市場へのマーケティングの必要性という 考え方から IM 議論が発展してきたが，IM の 知見を基に, 別の視点において IM を議論しよ

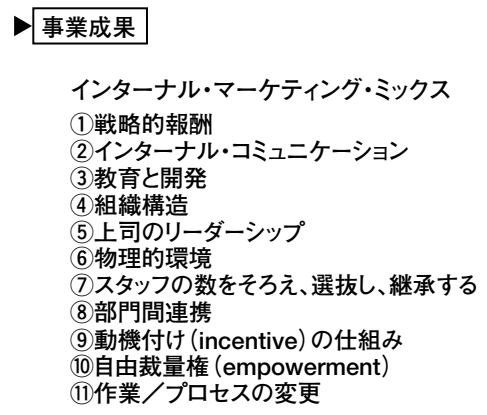

事業成果

インターナル・マーケティング・ミックス

(1) 戦略的報酬

インターナル・コミュニケーション

3)教育と開発

5)上司のリーダーシップ

6物理的環境

7)スタッフの数をそろえ、選抜し、継承する

10自由裁量権 (empowerment)

11)作業／プロセスの変更 
うと試みる研究も行われている。それまでの IM 研究においては, 組織内の従業員の動機付 けや連携の 1 プロセスとして知識や経験, 情報 の共有（Berry and Parasuraman, 1991）が扱 われているが，このIMの別の視点においては， 顧客のニーズやウォンツを満たすためにはこの 顧客に関する “知識”の創出と共有のための従 業員の管理こそが重要であるという視点, 即ち ナレッジ・マネジメントをIM の視点で捉えよ うという試みが行われている。Ballantyne (1997, 2003) やVarey and Lewis（1999）はこ の知識や経験の共有という点について, 組織内 の連携や従業員の動機付けの結果, 何を行って いるのか，何がうまくいって事業成果が上がる のかという疑問から IM を議論しており，実は 顧客と従業員間, 組織内での知識移転を行うこ とこそが重要であると主張している。

このナレッジ・マネジメント・アプローチに おける先駆的研究である Ballantyne（1997）は, 銀行の事例分析から，顧客に提供するサービス の品質改善, 顧客との良好な関係の構築, 長期 的な利益創出という一連のプロセスを IM より 捉え，知識という鍵となる概念を基に，図一 3 に示す IM プロセス・モデルを構築している。 彼はIMの実施には3つのプロセスを循環的に 回す事が重要となると主張している。まず1つ
目は従業員と顧客へのコミットメントである Energisingである。これはIM 研究の人的資源 管理アプローチにおいて議論されてきた, 従業 員と顧客, それぞれのニーズやウォンツの充足 が直線的な因果関係を持つという点を捉え直す ものである。Ballantyne（1997）においては， 業務が顧客志向である場合のみ，それぞれ正の 因果関係を持つとされる。2つ目は顧客の問題 を診断的に探し，知識を蓄積させるCodeBreaking である。IM では顧客の問題解決とい う部分にはあまり触れられてこなかったが，こ の部分が組織内の考え方や業務の変化のために は必要不可欠となる。3つ目のBorderCrossingは, 従来の IM 議論が対象としてきた 部分であるが, 組織の変化に対して組織内境界 の存在や，権限を持つ部門への負の影響などが 考えられるため，より注意深く IM を実施する 必要があるとされる。

この Ballantyne（1997）の研究は, 知識の創 造と共有という循環的プロセスを回すための IM に注目しただけでなく，そもそも数多くの IM 研究において, 顧客志向という点には触れ られながらも, 主な焦点が内部市場へのマーケ ティングのみに向いてしまっている事を指摘し， やはり IMの目的として顧客のニーズやウォン ツを満たすという点を意識すべきであると主張

口图-3

IM プロセス・モデル

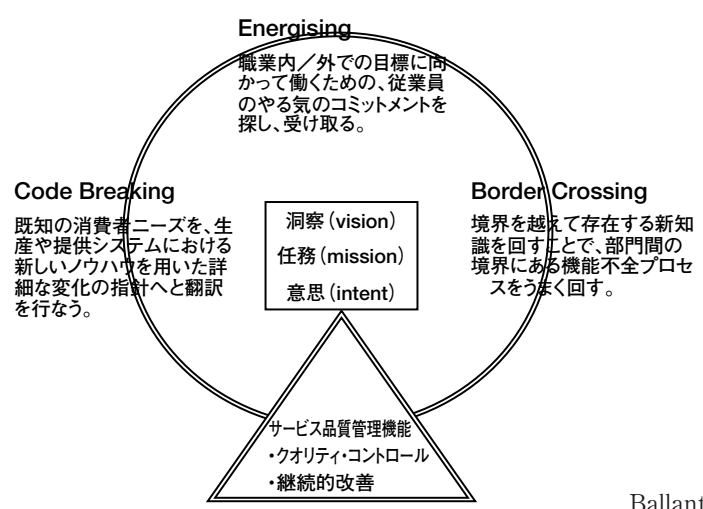

Ballantyne (1997), pp.335より筆者修正。 
テーマ書評シリーズ

するものとなっている。

Varey and Lewis (1999) p Dibb and Simkin（1999）も知識に焦点を当てたIM の重 要性について,「多くの企業が内的硬直性と知 識格差に苦しむ中，企業の成果を左右する鍵を 握るのがこの知識の移転であり，そのためには, 障壁を克服するためのマーケティング・スキル， 連携観念，現実主義と変化の受容，効果的関係 性, 助長と内的コミュニケーションが重要とな る」としている。これらの研究を基盤として Ballanyne（2003）は知識の創造と共有と IM について，Nonaka and Takeuchi（1995）の知 識創造モデルに即して IM と知識移転のモデル を構築している。彼はIM 「関係構築のため の（人的資源管理アプローチの）コミュニケー ションと, 組織的知識創造とは表裏一体であり, 関係構築を前提とした IM と知識創造プロセス との関係において議論する必要がある」と捉え ている。そこでは，部門間関係における信頼関 係やコミットメントの構築を基礎として議論さ れ，IM を知識移転のマーケティング施策と知 識更新のマーケティング施策に分類している。 構築されたモデル自体は Ballantyne（1997）の モデルを土台にされており，それを知識創造モ デルの4つのモードに即して細分化したもので ある。しかしながら，知識の移転が 3 つの移転 経路を通って行われる事を明らかにしている点 が重要な発見事項である。まず1つ目は，階層 的交換である。それは専門的知識が公式的階層 的チャネルを通って移転される経路であり，明 確なルールや暗黙の制約が必要となる。2つ目 は部門間交換である。これはバリューチェーン 内の内部供給者と内部顧客の間の移転経路であ り，顧客の必要性に依拠して起こるものである。 3つ目はネットワーク交換であり，知識が任意 の内部コミュニティ内で移転・循環 (共有)さ れる。この任意の従業員ネットワークは，共通 の社会的・経済的利益によって形成されるもの である。
これらナレッジ・マネジメント・アプローチ 研究において重要な点は, 顧客のニーズやウォ ンッを満たすために組織内で創造される知識を 移転し共有するという視点である。人的資源管 理アプローチにおいて Ahmed and Rafiq （1995）が，IM 実施をマルチレベルで捉える 事の必要性を説いているが，この知識という視 点を含めて IM の戦術的展開を考える事で，組 織内の各部分には障壁が存在し，その障壁を取 り除くためにIM を展開するという資源配分の 仕方ではなく，それぞれの経路において集中的 かつ効率的に資源配分することで，より効果的 な IM の戦術的展開が可能になると言える。つ まりその意味で，ナレッジ・マネジメント・ア プローチは“サービス提供には顧客のみならず 従業員も参加しており，その従業員の顧客志向 を醉成するために，組織的に効果的かつ効率的 な IMをどう展開するか”という人的資源管理 アプローチの域を越えていないと考えられるが， 知識という視点でIM を議論した功績は大きい と言える。

\section{知見のまとめと今後の課題}

以上，これまでの IM 議論について整理を行 った。組織内の従業員の全てが顧客のニーズや ウォンツを満たす事を目指し，常に顧客を意識 して行動する事を実現するのは容易では無い。 それは, Piercy and Morgan (1991) や Ahmed and Rafiq（1995）など多くの研究者が 指摘するように，組織内の各部門間の利害は決 して同じではなく，加えて業務に対しての考え 方や姿勢，従業員の特性などが異なるためであ る。この様な障壁が存在するために，多くの組 織において全ての従業員が顧客志向の下業務を 行う事が困難となっているのである。つまり， 顧客のニーズやウォンツを満たすためには，そ の実現を阻む組織内の障壁を把握し，組織的に それらを取り除き，全ての従業員が “顧客のた めに”業務に携わるという顧客志向の醉成が必 
要不可欠となる。言い換えると, 外部市場への マーケティングに先立って, 内部市場へのマー ケティングが不可欠となる。

また先行研究における課題として次の 4 点が 挙げられる。1つ目は, IM の事例研究のほと んどがサービス企業を対象にしたものであり， その他の産業における顧客志向の醸成と IM, 成果との関係については議論が不十分である。 2 つ目に，IM を効果的に実施するために求め られる, 経営者や中間管理職, 従業員の個人的 要因についても議論の余地が残る。3 点目は, IM 研究においては, その実施のための権限委 譲や組織変更といった組織の柔軟性は前提とし て扱われているが，それらが困難な組織におけ る IM の実施が可能かつ効果的なのかについて は議論が不十分であると言える。最後の 4 点目 は, IM 研究の焦点は組織内の顧客志向の醉成 であるが，企業間関係を対象にした場合の IM ついては議論が行われていない。先行研究から 導かれるこれら課題について, 今後の研究発展 が望まれる。

\section{注}

1）HP 創業者である D. Packardの「マーケティングは, マーケティング部門のみに任せるにはあまりにも重 要である」という言葉は, 組織全体とマーケティン グの関倸を象徵的に示している。

2）Albrecht（1988）は顧客第一を志向する企業にまず 求められる特徴として次の 7 点を挙げており, (1) 自 身の顧客についてもっと考えそして対話を行なう， (2)自身の顧客の認知・知覚を調查し続ける, (3) 顧客 に最も利益を与えるような重要な行動を行なうよう にする，(4)好意による価值が経済的利益を越えるよ うな状況を考える中で, 顧客に屈し, 譲歩し, 価值 を付与する，(5)実際の失敗や不手際を誠実に償う， (6)不满足の顧客や特別なニーズを持つ顧客に対して, 状況を改善するためには「どれだけ労力がかかって も」という考えの採用，(7)サービス品質の向上が阻 害されているときは，システムを組み換え，資源の 配置換えを行い，おびえた牛を放牧させる，といっ た特徴である。そして, その企業として, スカンジ ナビア・エアラインの事例を紹介している。

3）Zaithmal et al.（1988）においては, 経営者から従
業員へのコミュニケーションの頻度と質と正確さが 高ければ高いほど，従業員自身の役割についての曖 昧さが減少し, 結果として仕事への満足と達成感が 高まるという点について実証研究を行っている。類 似した研究に, Walker et al. (1975) があり, 従業 員に対しての明確な基準の下での教育を行うことで, 従業員の仕事への瞹昧さが減少し, 結果として仕事 への満足が高まるという研究もある。

4） Norman（1991）では，管理運営がうまくいってい ない組織内で聞かれる声を整理した表が示されてい る。

5) Collins and Payne（1991）に拈いて，IM の戦術的 活動は, 組織目標における重要度とカスタマイズの 必要性の 2 軸で捉えられており，1）カスタマイズ するスキルとコンサルテーションのスキルが要求さ れる “顧客志向”，2）標準的スキルや課題の調整能 力が要求される “プログラム志向”，3）開発スキル やプロジェクト統制能力が要求される “柔軟なアプ ローチ”，4）作業のコントロールや調整能力が要求 される “外注による解決”に分類出来ると示されて いる。

6）各 IM ミックスの測定については, Ahmed et al. （2003）, pp.1229, 1236 を参照されたい。

\section{参考文献}

Ahmed, P. K. and Rafiq, M. (1995), “The Role of Internal Marketing in the Implementation of Marketing Strategies," Journal of Marketing Practices, 1 (4), pp.32-51.

Ahmed, P. K., Rafiq, M., and Saad, N. M. (2003), “Internal Marketing and the Mediating Role of Organizational Competencies," European Journal of Marketing, 37 (9), pp.1221-1241.

Albrecht, K. (1988), At America's Service, Dow Jones-Irwin.

Babakus, E. and Boller, G. W. (1992), “An Empirical Assessment of the SERVQUAL Scale," Journal of Business Research, 24(3), pp.253-268.

Ballantyne, D. (1997), “Internal Networks for Internal Marketing," Journal of Marketing Management, 13, pp.343-366.

- (2003), “A Relationship-Mediated Theory of Internal Marketing," European Journal of Marketing, 37 (9), pp.1242-1260.

Baron, S. and Harris, K. (1995), Service Marketing, Macmillan Press.

Bateson, J. E. G. (1979), “Why We Need Service Marketing," in Fornell, O. C., Bowen, S. W., and Lamb, Jr. C. W., (eds.), Conceptual and Theoretical 
Development in Marketing, Chicago: American Marketing Association, pp.131-146.

- (1991), “Understanding Services Consumer Behavior," in Congram, C. A., (eds.), The AMA Handbook of Marketing for the Services Industries, AMACOM, pp.135-149.

Berry, L. L. (1981), “The Employee as Customer,” Journal of Retail Banking, 3 (1), pp.33-40.

Berry, L. L. and Parasuraman, A. (1991), Marketing Services, Competing Through Quality, The Free Press.

Bitner, M. J. (1990), “Evaluating Service Encounters: The Effects of Physical Surroundings and Employee Responses,” Journal of Marketing, 54, April, pp.69-82.

Bowen, D. E. and Lawler, E. E. (1992), “The Empowerment of Service Workers: What, Why, How, and When," Sloan Management Review, Spring, pp.31-39.

Carlzon, J. (1987), The Moment of Truth, Ballinger, New York.（堤猶二訳，『真実の瞬間：SAS のサービス 戦略はなぜ成功したか』,ダイヤモンド社)

Carman, J. M. (1990), “Consumer Perceptions of Service Quality: An Assessment of the SERVQUAL Dimensions," Journal of Retailing, 66 (1), pp.33-55.

Collins, B. and Payne, A. (1991), “Internal Marketing: A New Perspective for HRM," European Management Journal, 9 (3), pp.261-270.

Cronin, J. J. Jr. and Taylor, S. A. (1992), "Measuring Services Quality: A Reexamination and Extension," Journal of Marketing, 56, July, pp.55-68.

Crosby, L. A., Evans, K. R., and Cowles, D. (1990), "Relationship Quality in Service Selling: An Interpersonal Influence Perspective," Journal of Marketing, 54, July, 68-81.

Dibb, S. and Simkin, L. (2000), “ Pre-Empting Implementation Barriers: Foundations, Processes and Actions ミ The Need for Internal Relationships," Journal of Marketing Management, 16, pp.483-503.

George, W. R. (1990), “ Internal Marketing and Organizational Behavior: A Partnership in Developing Customer-Conscious Employee at Every Level," Journal of Business Research, 20(1), pp.63-70.

Glassman, M. and McAfee, B. (1992), “Integrating the Personnel and Marketing Functions: the Challenge of the 1990s," Business Horizons, 35 (3), pp.52-59.

Gronroos, C. (1981), “Internal Marketing: An Integral Part of Marketing Theory," in Donnelly, J. H. and George, W. E. (eds.), Marketing of Services, American Marketing Association Proceedings Series, pp.236-238.

Gummesson, E. (1987), “Using Internal Marketing to Create a New Culture: The Case of Ericsson Quality," Journal of Business and Industrial Marketing, 2 (3), pp.23-28.

(1991), “Marketing-Orientation Revisited: The Crucial Role of the Part-Time Marketer," European Journal of Marketing, 25 (2), pp.60-75.

藤村和宏 (1995), 「顧客のサービス・デリバリー・プロ セスへの参加と品質評価一医療サービスにおける 外来及び入院患者の評価を中心としてー」，『香川 大学経済論叢』,68 (1), pp.119-172.

Judd, R. C. (1964), “The Case for Redefining Services," Journal of Marketing, 28, January, pp.58-59.

Lings, I. N. (2000), "Internal Marketing and Supply Chain Management,” Journal of Services Marketing, 14 (1), pp.27-43.

Nonaka, I. and Takeuchi, H. (1995), The Knowledge Creating Company: How Japanese Companies Create the Dynamics of Innovation, Oxford University Press, New York, NY.

Norman, R. (1991), Service Management: Strategy and Leadership in Service Business, John Wiley and Sons.

Oliver, R. L. (1980), "A Cognitive Model of the Antecedents and Consequences of Satisfaction Decisions," Journal of Marketing Research, 27, November, pp.460-469.

Parasuraman, A., Zeithmal, V. A., and Berry, L. L. (1988), "SERVQUAL: A Multiple-item Scale for Measuring Consumer Perceptions of Service Quality, Journal of Retailing, 64(1), pp.12-37.

Piercy, N. and Morgan, N. (1991), “Internal Marketing: the Missing Half of the Marketing Programme," Long Range Planning, 24 (2), pp.82-93.

Rathmel, J. M. (1966), “What is Meant by Services?," Journal of Marketing, 30, October, pp.32-36.

Rafiq, M. and Ahmed, P. K. (1993), “The Scope of Internal Marketing: Defining the Boundary Between Marketing and Human Resource Management," Journal of Marketing Management, 9, pp.219-232.

- (2000), “Advances in the Internal Marketing Concept: Definition, Synthesis and Extension,” Journal of Services Marketing, 14 (6), pp.449-462.

Regan, W. J. (1963), “The Service Revolution,” Journal of Marketing, 27, July, pp.57-62.

Sasser, W. R. and Arbit, P. (1976), "Selling Jobs in the Service Sector,” Business Horizon, June, pp.61-64.

Shostack, G. L. (1984), “Designing Services That Deliver," Harvard Business Review, 62, January-February, pp.133-139.

— (1987), “Service Positioning Through Structual 
Change," Journal of Marketing, 51, January, pp.34-43.

Solomon, M. R., Surprenant, C., Czepiel, J. A., and Gutman,

E. G. (1985), “A Role Theory Perspective on Dynamic Interactions: The Service Encounter," Journal of Marketing, 49, Winter, pp.99-111.

Varey, R. J. (1995), “A Model of Internal Marketing for Building and Sustaining Competitive Service Advantages," Journal of Marketing Management, 11, pp.45-52.

Varey, R. J. and Lewis, B. R. (1999), “A Broadened Conception of Internal Marketing," European Journal of Marketing, 33 (9), pp.926-944.

Vasconcelos, A. F. (2008), "Broadening Even More the Internal Marketing Concept," European Journal of Marketing, 42 (11), pp.1246-1264.

Walker, O. C., Churchill, G. A., and Ford, N. M. (1975), "Organizational Determinants of the Industrial Salesman's Role and Ambiguity," Journal of Marketing, 39, January, pp.32-39.

山本昭二 (1999), 『サービス・クォリティ』, 千倉書房.

Zeithmal, V. A., Berry, L. L., and Parasuraman, A. (1988), "Communication and Control Processing in the Delivery of Service Quality," Journal of Marketing, 52, April, pp.35-48.

森村 文一（もりむら ふみかず）

1982 年生まれ，2005 年立命館大学経済学部卒業後, 現在神戸大学大学院経営学研究科博士課程後期課程

に在学中。

専攻は, 消費者行動論及びマーケティング論

e-mail : fumikazumorimura@stu.kobe-u.ac.jp 